\title{
New and rare for the Belarusian fauna True Bug species (Insecta: Hemiptera: Heteroptera) from the parks of Brest Region
}

\author{
Новые и редкие дмя фауны Беларуси виды настоящих \\ полужесткокрылых (Insecta: Hemiptera: Heteroptera) из парков \\ Брестской обцасти
}

\author{
A.O. Lukashuk ${ }^{1}$, S.V. Saluk ${ }^{2}$ \\ A.O. Аукашук ${ }^{1}$, С.В. Салук ${ }^{2}$
}

\footnotetext{
${ }^{1}$ Berezinskiy Biosphere Reserve, Domzheritsy, 211188, Lepel Distr., Vitebsk Reg., Belarus. E-mail: lukashukao@tut.by

${ }^{2}$ Scientific-practical Center for Biological Resources, National Academy of Sciences of Belarus, Akademicheskaya Str. 27. Minsk, 220072, Belarus. E-mail: ssaluk@yandex.ru

${ }^{1}$ Государственное природоохранное учреждение «Березинский биосферный заповедник», Управление делами Президента Республики Беларусь, 211188, д. Домжерицы, Лепельский р-н, Витебская обл.

${ }^{2}$ Государственное научно-производственное объединение «Научно-практический центр Национальной академии наук Беларуси по биоресурсам», Национальная академия наук Республики Беларусь, ул. Академическая, 27, 220072, Минск.
}

KEY WORDS: Fauna, true bugs, Hemiptera, Heteroptera, parks, Brest Region.

КЛЮЧЕВЫЕ СЛОВА: Фауна, настоящие полужесткокрылые, Hemiptera, Heteroptera, парки, Брестская область.

ABSTRACT. Four species of true bugs, Acalypta parvula (Fallén, 1807), Agnocoris reclairei (Wagner, 1949), Orius laticollis laticollis (Reuter, 1884), Taphropeltus contractus (Herrich-Schaeffer, 1835), and one genus, Taphropeltus Stål, 1872, are reported in the article in Belarus for the first time. They were discovered during the study of the biodiversity of parks in the Brest region. Also, data on the distribution of several true bugs species known to be rare in Belarus are given.

РЕЗЮМЕ. В статье впервые для территории республики Беларусь приводится четыре вида настоящих полужесткокрылых: Acalypta parvula (Fallén, 1807), Agnocoris reclairei (Wagner, 1949), Orius laticollis laticollis (Reuter, 1884), Taphropeltus contractus (Herrich-Schaeffer, 1835) и один род Taphropeltus Stål, 1872, обнаруженных при исследовании биоразнообразия парков Брестской области, а также данные по распространению ряда редких для республики клопов.

\section{Introduction}

The problem of biodiversity, its study and conservation, is well-know and remains actual. In that respect, parks, usually relatively old stands with trees aging 200 hundred years, more or less isolated from the natural ecosystems, with considerable amount of introduced plant species and relatively mild management regimes, present a special interest.

On one side, parks help to maintain the local biodiversity, especially species associated with old trees [Carpaneto et al., 2010; Ehnström, Rieger, 1986; Jonsell, 2004]. The example of Arocatus melanocephalus (Fabricius, 1798) (Lygaeidae), associated with old ash trees and declined in such trees possibly triggered the species 200-250 km northward expansion and inclusion into the catgory of rare species, is exemplary in that respect [Pericart, 1998 a].

On the other side, parks may facilitate introduction and spread of unwanted adventive species, including not just associates of introduced plants, but predatory species as for example Amphiareus obscuriceps (Poppius, 1909), Far Eastern member of Anthocoridae, recorded also in Brest Region parks in Kobrin (Kobrin District) and Malye Sekhnovichi (Zhabinka District).

However, biodiversity studies in Belarusian park are sporadic. While plants and historic and cultural heritage have some bibliography [Antipov, 1975; Nestsyarchuk, 1999, 2002; Fedoruk, 2006], only single paper is published on the zoological component of the park biodiversity [Ryndevich et al., 2008] listing 73 species from 17 true bug families for 14 old parks in Baranovichi District.

How to cite this article: Lukashuk A.O., Saluk S.V. 2021. New and rare for the Belarusian fauna True Bug species (Insecta: Hemiptera: Heteroptera) from the parks of Brest Region // Russian Entomol. J. Vol.30. No.1. P.16-19. doi: 10.15298/rusentj.30.1.03 


\section{Material and Methods}

The fieldwork was carried out in 12 old parks situated in 6 Districts of the Brest Region, this paper uses the data from five parks in four Districts: Beryosa, Drogichin, Kobrin and Zhabinka (Fig. 1).

Detailed descriptions of these and many other old parks of the Region can be found in the fundamental work of Fedoruk [2006].

1. Park in the former Kościuszko's estate (Malye Sekhnovichi Village, Zhabinka District: N52 ${ }^{\circ} 11^{\prime} 35^{\prime \prime}$ E24 $\left.00^{\prime} 26^{\prime \prime}\right)$. Established in XVIII-XIX centuries. Tree species of the park include horse chestnut, European and American limes, ash, oak, maple, hornbeam, birch, Canadian poplar [Fedoruk, 2006].

2. Park in the former Moloczewski's estate (Peski Village env., Kobrin District: N52 $14^{\prime} 12^{\prime \prime}$ E24 $12^{\prime} 30^{\prime \prime}$ ). Established in XIX century, area is 3 ha. Tree species of the park include maple, large-leaved lime, spruce, pine, hornbeam, black locust, larch, goat willow and horse chestnut.

3. Park in the former Tysenhaus' estate (Town of Kobrin: N52 ${ }^{\circ} 12^{\prime} 03^{\prime \prime}$ E $\left.24^{\circ} 21^{\prime} 03^{\prime \prime}\right)$, currently a part of the A. V. Suvorov's Park. Established in 1768, rectangular in shape, with a regular alley system, current area over 40 ha. Trees and shrubs of the park include about 70 species, oak, maple, hornbeam, ash, white poplar, blue spruce, black locust, staghorn sumac, Sawara cypress, Billard's spirea, Virginia creeper etc., several lime trees ca. 250 years old are preserved.

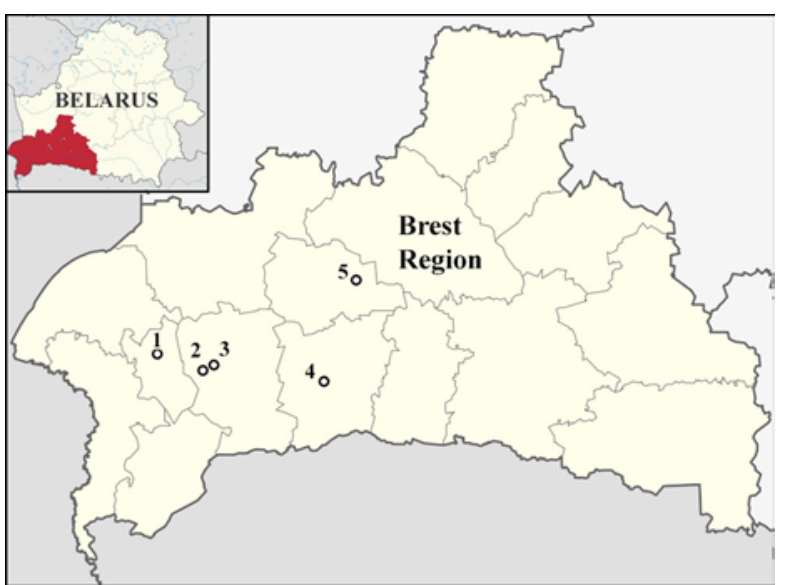

Fig. 1. The localities of new and rare the true bugs species (Heteroptera) registered in Brest Region: 1 - fragment of the park in the former Kościuszko's Estate (Malye Sekhnovichi Village, Zhabinka District); 2 - park of the former Moloczewski's Estate (Peski Village, Kobrin District); 3 - Suvorov Park (Kobrin Town) 4 - park of the former Wyslouch's Estate (Perkovichi Village, Drogichin District); 5 - park of the former Puslowski's Estate (Peski Village, Beryoza District.

Рис. 1. Места регистрации новых и редких видов настоящих полужесткокрылых (Heteroptera) на территории Брестской области: 1 - фрагмент парка в имении Костюшек (д. Малые Сехновичи, Жабинковский район); 2 - парк панов Молочевских (д. Пески, Кобринский район); 3 - парк им. Суворова (г. Кобрин); 4 - парк панов Вислоухов (д. Перковичи, Дрогиченский район); 5 - парк графов Пусловских (д. Пески, Березовский район).
4. Wyslouch's palace-park ensemble (Perkovichi Village, Drogichin District: N52 $10^{\prime} 34^{\prime \prime}$ E2501'39"). Established in early XIX century. Tree species of the park include oak, maple, ash and lime.

5. Puslowski's estate-park ensemble (Peski Village, Beryoza District: N52 $29^{\prime} 27^{\prime \prime}$ E25 $\left.5^{\circ} 2^{\prime} 49^{\prime \prime}\right)$. Established in the second half of the XVIII century. Tree species of the park include silver maple, red oak, green ash and hornbeam, some limes and beeches are almost 200 years old.

Insects were collected by a variety of standard methods [Golub et al., 2012]: net sweeping, hand picking from the plants, soil surface, under bark and in tree holes, sifting of leaf litter and rotten wood.

\section{Results and Discussion}

We recorded four true bug species, Acalypta parvula (Fallén, 1807), Agnocoris reclairei (Wagner, 1949), Orius laticollis laticollis (Reuter, 1884), Taphropeltus contractus (Herrich-Schaeffer, 1835), and one genus, Taphropeltus Stål, 1872, for the first time in Belarus. Collections of five more species represent some faunistic interest.

\section{Family Tingidae \\ Acalypta parvula (Fallén, 1807)}

MATERIAL. 107, Brest Region, Drogichin District, Perkovichi Village, Wyslouch's estate-park, in rotten stumps of deciduous trees, 26.08.2016, S.V. Saluk leg.

NOTES. Recorded for Belarus for the first time. One of 29 palearctis species of the genus [Aukema, Rieger, 1996], six species are recorded in Belarus.

The species has microhabitat and trophic connections with green mosses, also occurs on some other plants, Genista, Calluna, Thymus, Ulex, growing in moss-covered areas. Overwintering stage — imago [Péricart, 1983].

DISTRIBUTION. Europe: Austria, !Belarus, Belgium, Bulgaria, Croatia, Czech Republic, Denmark, Estonia, Finland, France, Germany, Greece, Great Britain, Denmark, Ireland, Italy, Hungary, Liechtenstein, Luxembourg, Montenegro, Norway, Poland, Portugal, Romania, Russia (North and Central European parts), Serbia, Slovakia, Slovenia, Spain, The Netherlands, Sweden, Switzerland. North Africa: Algeria, Azores, Canary Islands, Madeira, Tunisia. Nearctic: Canada, USA [Aukema, Rieger, 1996].

\section{Family Miridae}

Agnocoris reclairei (Wagner, 1949)

MATERIAL. $30^{7} 0^{7}$ : $10^{7}$, Brest Region, Kobrin Town, A.V. Suvorov Park, sweeping, 25.07.2011, A.O. Lukashuk leg.; $20^{7} \sigma^{7}$, same place, locality, but 27.07.2011, A.O. Lukashuk leg.

NOTES. Recorded for Belarus for the first time. One of three Palearctic species of the genus [Aukema, Rieger, 1999], two of which are known in Belarus.

The species has microhabitat and trophic connections with willows (Salix spp.). Overwintering stage imago.

DISTRIBUTION. Europe: Austria, !Belarus, Bulgaria, Croatia, Czech Republic, France, Germany, Great Britain, Italy, Hungary, Liechtenstein, ?Luxembourg, North Macedonia, Moldova, Montenegro, The Netherlands, Poland, Russia (South European part), Serbia, Slovakia, Slovenia, Spain, Turkey, Ukraine, Switzerland. Asia: Azerbaijan, Turkey, Iraq [Aukema, Rieger, 1999]. 


\section{Orthonotus rufifrons (Fallen, 1807)}

MATERIAL. 10'. Brest Region, Kobrin Town, A.V. Suvorov Park, sweeping, 25.07.2011, A.O. Lukashuk leg.

NOTES. One of 19 Palearctic species of the genus [Aukema, Rieger, 1999] represented in Belarus by a single species. Rare species for the local fauna, has microhabitat and trophic connections with nettles (Urtica spp.). Overwintering stage egg [Wagner, Weber, 1964].

DISTRIBUTION. Europe: Austria, !Belarus, Belgium, Bosnia Herzegovina, Bulgaria, Croatia, Czech Republic, Denmark, Estonia, Finland, France, Georgia, Germany, Great Britain, Ireland, Italy, Hungary, Latvia, Liechtenstein, Luxembourg, Macedonia, Moldova, Montenegro, Norway, Poland, Romania, Russia, Serbia, Slovakia, Slovenia, Spain, The Netherlands, Turkey, Ukraine, Sweden, Switzerland. Asia: Armenia, Azerbaijan, Turkey [Aukema, Rieger, 1999].

\section{Family Anthocoridae}

Orius laticollis laticollis (Reuter, 1884)

MATERIAL. $1 \sigma^{\top}$, Brest Region, Kobrin Town, A.V. Suvorov Park, 09.08.2011, A.O.Lukashuk leg.

NOTES. Recorded for Belarus for the first time. One of 25 Palearctic species of the genus [Aukema, Rieger, 1996], five of which are known in Belarus.

Rare spies, predator living on shrubs and trees (often on Salix) and umbelliferous plants in wet habitats; also reported from Artemisia sp. Overwintering stage imago [Pericart, 1972].

DISTRIBUTION. Europe: Austria, !Belarus, Belgium, Bosnia Herzegovina, Bulgaria, Croatia, Czech Republic, Denmark, France, Germany, Great Britain, Greece, Hungary, Italy, W Kazakhstan, Luxembourg, North Macedonia, Moldova, Montenegro, Poland, Portugal, Romanià, Serbia, Slovakia, Slovenia, The Netherlands, ?Ukraine, Sweden, Switzerland. Asia: Kazakhstan, Korea, Mongolia, Russia (East Siberia, Far East), ?Syria, Turkey [Aukema, Rieger, 1996].

\section{Familia Lygaeidae}

\section{Raglius alboacuminatus (Goeze, 1778)}

MATERIAL. 1 ex., Brest Region, Drogichin District, Perkovich Village, Wyslouch's park, rotten stumps of deciduous trees, 26.08.2016, S. V. Saluk leg.; 1 ex., Brest Region, Zhabinka District, Malye Sekhnovichi Village, park, Acer platanoides living tree (rotten wood, fungi, dry leaves, sap flow), 27.09.2016, S. V. Saluk leg.

NOTES. One of five Palearctic species of the genus [Aukema, Rieger, 1999], the only species known in Belarus.

Rare in collections, plant feeding polyphagous species, inhabiting primarily soil surface and leaf litter, in search of seeds may climb herbaceous plants and tree trunks. Overwintering stage imago, sometimes gather in high quantities [Pericart, 1998c].

DISTRIBUTION. Europe: Albania, Andorra, Austria, Belarus, Belgium, Bosnia Herzegovina, Bulgaria, Croatia, Czech Republic, Denmark, Estonia, Finland, France, Germany, Great Britain, Ireland, Italy, Hungary, Latvia, Liechtenstein, Luxembourg, North Macedonia, Moldova, Montenegro, Norway, Poland, Portugal, Romania, Russia (Central and South European parts), Serbia, Slovakia, Slovenia, Spain, The Netherlands, Turkey, Ukraine, Sweden, Switzerland. North Africa: Algeria, Canary Islands, Madeira, Morocco, Tunisia. Asia: Armenia, Azerbaijan, Cyprus, Georgia, Israel, Iran, Kazakhstan, Kyrgyzstan, Russia (West Siberia), Syria, Tajikistan, Turkey, Turkmenistan, Uzbekistan [Aukema, Rieger, 1999].

\section{Scolopostethus pictus (Schilling, 1829)}

MATERIAL. 1 ex., Brest Region, Beryoza District, Peski Village, park, in rotten wood of Acer platanoides living tree, 26.09.2016, S.V. Saluk leg.
NOTES. One of 18 Palearctic species of the genus [Aukema, Rieger, 1999], six species are recorded in Belarus.

Lives on soil surface and leaf litter in wet places, supposedly suck on fungus hypae and various plant seeds. Overwintering stage imago and nymphs, the latter needs confirmation for Belarus [Pericart, 1998b].

DISTRIBUTION. Europe: Albania, Andorra, Belarus, Belgium, Bosnia Herzegovina, Bulgaria, Croatia, Czech Republic, Estonia, Finland, France, Germany, Great Britain, Greece, Italy, Hungary, Latvia, Liechtenstein, Luxembourg, North Macedonia, Malta, Moldova, Montenegro, Norway, Poland, Portugal, Romania, Russia, Serbia, Slovakia, Slovenia, Spain, The Netherlands, Turkey, Ukraine, Sweden, Switzerland. North Africa: ?Morocco. Asia: Azerbaijan, Cyprus, Georgia, Israel, Iran, Jordan, Lebanon, Russia (West Siberia), Turkey, [Aukema, Rieger, 1999].

\section{Taphropeltus contractus (Herrich-Schaeffer, 1835)}

MATERIAL. 1 ex., Brest Region, Kobrin District, Peski Village, park, Molochewszczina Valley, in rotten stump of Carpinus betulus. S.V. Saluk leg.

NOTES. One of six Palearctic species of the genus [Aukema, Rieger, 2001], the only species known in Belarus. Recorded for Belarus for the first time.

Plant-eating polyphage inhabiting soil surface, leaf litter, moss cover, suck on various plant seeds. Overwintering stage imago [Pericart, 1998b].

DISTRIBUTION. Europe: Albania, Andorra, Austria, !Belarus, Belgium, Bosnia Herzegovina, Bulgaria, Croatia, Czech Republic, France, Germany, Great Britain, Greece, Ireland, Italy, ?Hungary, Latvia, Liechtenstein, Luxembourg, North Macedonia, Malta, Moldova, Montenegro, Norway, Poland, Portugal, Romania, Russia (South European part), Serbia, Slovakia, Slovenia, Spain, The Netherlands, Turkey, Ukraine, Sweden, Switzerland. North Africa: Algeria, Morocco, Tunisia. Asia: Azerbaijan, Turkey [Aukema, Riger, 2001].

\section{Familia Rhopalidae}

Brachycarenus tigrinus (Schilling, 1829)

MATERIAL. 1 ex., Brest Region, Zhabinka District, Malye Sekhnovichi Village, park, Acer platanoides living tree (rotten wood, fungi, dry leaves, sap flow), 27.09.2016, S.V. Saluk leg.

NOTES. One of two Palearctic species of the genus [Aukema, Rieger, 2006], the only and rare species known in Belarus.

Inhabits soil surface, leaf litter, plan detritus and hebracious plants; plant-feeding oligophagus species on Brassicaceae plants. Overwintering stage imago [Puchkov, 1986].

DISTRIBUTION. Europe: Albania, Austria, Belarus, Belgium, Bosnia Herzegovina, Bulgaria, Croatia, Czech Republic, Denmark, Finland, France, Germany, Great Britain, Greece, Italy, ?Hungary, Kazakhstan, Luxembourg, North Macedonia, Malta, Moldova, Montenegro, Norway, Poland, Portugal, Romania, Russia, Serbia, Slovakia, Slovenia, Spain, Sweden, Switzerland, The Netherlands, Turkey, Ukraine. North Africa: Algeria, Azores, Canary Islands, Madeira, Morocco, Tunisia. Asia: Armenia, Afghanistan, Azerbaijan, China (North, North-West, West, South-West), Cyprus, Georgia, Israel, Iran, Iraq, Jordan, Kazakhstan, Kyrgyzstan, Mongolia, Pakistan (Kashmir), Russia (Siberia), Tajikistan, Turkey, Turkmenistan, Uzbekistan. Nearctic: introduced to USA [Aukema, Rieger, 2006].

\section{Familia Plataspidae}

Coptosoma scutellatum (Geoffroy, 1785)

MATERIAL. 2 ex., Brest Region, Kobrin, A.V. Suvorov Park, sweeping 25.07.2011, A.O. Lukashuk leg. 
NOTES. One of 57 Palearctic species of the genus [Aukema, Rieger, 2006], the only species recorded in Belarus.

Imago live and feed on Fabaceae plants. Nymphs leave plants after feeding for soil surface till the next feeding bout. Overwintering stage nymphs of III-IV stage, this needs confirmation for Belarus [Puchkov, 1961].

DISTRIBUTION. Europe: Albania, Austria, Belarus, Belgium, Bosnia Herzegovina, Bulgaria, Croatia, Czech Republic, France, Germany, Greece, Denmark, Italy, Hungary, Kazakhstan, Latvia, Litva, Liechtenstein, Luxembourg, North Macedonia, Moldova, Montenegro, Poland, Romania, Russia, Serbia, Slovakia, Slovenia, Spain, The Netherlands, Turkey, Ukraine, Sweden, Switzerland. North Africa: Algeria. Asia: Armenia, Azerbaijan, China (North-West, North, NorthEast), Georgia, Japan, Kazakhstan, Korea, Kyrgyzstan, Mongolia, Russia, Turkey [Aukema, Rieger, 2006].

Thus, one genus, Taphropeltus Stål, 1872, and four species, Acalypta parvula, Agnocoris reclairei, Orius laticollis laticollis and Taphropeltus contractus, are reported from the Belarusian territory for the first time.

Acknowlegments. Our cordial gratitude goes to P.S. Prokhorchik (Minsk, Belarus) for the field work assistance, E.M. Setrakova (Minsk, Belarus) for the help in locating some hardly accessible papers, K.V. Makovetskaya (Minsk, Belarus) for some editorial help in the manuscript preparation and our old friend and colleague A.K. Tishechkin (Sacramento, USA) for improving the English. Study is a contribution from the Belarusian Republican Foundation for Fundamental Research Project No. 516-097 (20.06.2016, "Ecological potential of old parks and alleys of Belarus as habitats for rare species listed in national and IUCN Red Data Book of insects").

Competing interests. The authors declare no competing interests.

\section{References}

Antipov V.G. 1975. [Parks of Belarus]. Minsk: Uradzhay. 200 pp. [In Russian]

Aukema B., Rieger Ch. 1996. Catalogue of Heteroptera of the Palaearctic Region. Vol.2. Netherlands Entomological Society. $361 \mathrm{pp}$.
Aukema B., Rieger Ch. 1999. Catalogue of Heteroptera of the Palaearctic Region. Vol.3. Netherlands Entomological Society. 577 pp.

Aukema B., Rieger Ch. 2001. Catalogue of Heteroptera of the Palaearctic Region. Vol.4. Netherlands Entomological Society. 346 pp.

Aukema B., Rieger Ch. 2006. Catalogue of Heteroptera of the Palaearctic Region. Vol.5. Netherlands Entomological Society. $550 \mathrm{pp}$.

Carpaneto G.M., Mazziotta A., Coletti G., Luiselli L., Audisio P. 2010. Conflict between insect conservation and public safety: the case study of a saproxylic beetle (Osmoderma eremita) in urban parks // Journal of Insect Conservation. Vol.14. P.555-565.

Ehnström B., Rieger Ch. 1986. Faunavård i skogsbruket Den lägre faunan. Skogsstyrelsen: Jönköping. 277 pp.

Fedoruk A.T. 2006. [The old estates of Beresteyshchina]. Minsk: BelEn. 576 pp. [In Russian]

Golub V.B., Tsurikov M.N., Prokin A.A. 2012. [Insect collections: collection, processing and storage of material]. Moscow: KMK Scientific Press. 339 pp. [In Russian]

Jonsell, M. 2004. Old park trees: a highly desirable resource for both history and beetle biodiversity // J. Arboric. Vol.30. P.238-244.

Nestsyarchuk L.M. 1999. [Palaces, parks, castles of Baranavitskag district: history, camp, prospects]. Brest: Abldrukarnya. 80 pp. [In Belarusian]

Nestsyarchuk L.M. 2002. [Castles, palaces, parks Berasceyshchyny $\mathrm{X}-\mathrm{XX}$ centuries (history, camp, prospects)]. Minsk: BELTA. 336 pp. [In Belarusian]

Pericart J. 1972. Hémiptères, Anthocoridae, Cimicidae et Microphysidae, de l'ouest-paléarctique. Paris: Masson et $C^{\text {ie }}$ Éditeurs. $402 \mathrm{pp}$.

Péricart J. 1983. Hémiptères Tingidae euro-méditerranéens // Faune de France. Vol.69. 618 pp.

Pericart J. 1998a. Hémiptères Lygaeidae euro-méditerranéens. Vol.1// Faune de France. Vol.84A. 468 pp.

Pericart J. 1998b. Hémiptères Lygaeidae euro-méditerranéens. Vol.2 // Faune de France. Vol.84B. 456 pp.

Pericart J. 1998c. Hémiptères Lygaeidae euro-méditerranéens. Vol.3 // Faune de France. Vol.84C. 489 pp.

Puchkov V.G. 1961. [Shchytnyky] // Fauna of Ukraine. T.21. Iss.1. Kiev: Vidavnistvo Academy of Sciences of the Ukrainian SSR. 338 pp. [In Ukrainian]

Puchkov V.G. 1986. [Hemiptera of the family Rhopalidae (Heteroptera) of the fauna of the USSR]. Leningrad: Nauka. 132 pp. [In Russian]

Ryndevich S.K., Ryndevich A.G., Zuev V.N. 2008. Ancient parks of Baranovichi region: biodiversity reserves and ecotourism objects. Baranovichi: RIO BarGU: 239 pp. [In Russian]

Wagner E., Weber H.H. 1964. Hétéroptères Miridae // Faune de France. Paris. Vol.67. 591 pp. 